bour has sunk, we were not aware that the valıe of a pauper's arm in Bridgewater had fallen so low as five pounds. The Guardians who made Mr. WARD their servile instrument, may afford to commit several such crimes in the course of the year; the saring arising from paupers dead and not maimed, will furnish many sums of $£ 5$. Under the barbarous jurisprudence of the Normans injury was atoned for by pecuniary fines; the eye, the ear, the leg, the arm the life were valued, and the mulct effaced the crime; but it does not appear, after taking into account the difference in the value of money, that a lower price was even set upon a human arm, even after the Norman conquest, when the country was barbarous, and its face was covered with violence. These ill-advised and cruel measures will inevitably lead the people of Bridgewater to inquire what is the value of a Guardian's neck, where a woman's arm is ralued at $£ 5$, and paupers' lives are weighed down by water gruel.

\section{POOR-LAW UNIONS.}

\section{To the Editor of The Lancet.}

SiR:-I am glad to see in your leading article on the "causes of increased mortality in large cities," allusions made to the parochial medical officers of this country; which lead to the persuasion that your influence as a member of the Legislature, as well as your power as a Journalist, is eulisted on the side of justice and humanity.

Will you allow me to offer a remark or two on your proposition, that there should he a Medical Guardian for each Union, and a Medical Cummissioner for all the Unions together.

In this Union, as you are perhaps aware, we have had at each election, a medical man elected to be Guardian; und in the PoorLaw Commission, we have, as yon are also aware, Dr. Kay for an Assistant, or perhaps he should rather be called, a working Commissioner. What benefit have the sick poor and the medical profession in the Kensington Uuion derived from the presence of Messis. Chinnock and Morrah, successively at the Board of Guardians? And how far has Dr. Kay's professional knowledge modified the whoelsale insults and injustice with which the irofession at large bis been treated by his brother Commissioners?
My answer to both these questions shall be facts, "damning facts," as Shakespeare calls them. And you and your readers can form your own conclusions upon those facts. To Mr. Chinnock, of Brompton, the division of Chelsea parish under the first Board of Guardians was confided. To his judgment, in all cases affecting the medical department his brother Guardians very generally deferred. Mr. Chinnock divided the parish into two districts, north and south, the boundary line being the King's private road. The number of sick paupers somewhat preponderating on the south side, but the workhouse, now the Union Infirmary, for all female cases, being on the north.

This took place in 1837. Ten years before, the parish was governed by a committee, who appointed a medical officer for the whole parish, with $\$ 300$ a year; an assistant to dispense nedicine, and afford occasional relief to the sick poor in cases of emergency; and a parochial dispensary, the expense of which to the parish, averaged from $60 l$. to $100 t$. per annum. The population of the parish did not certainly exceed that of the present time. It is now estimated-under estimated -at upwards of 32,000 inhabitants. A subsequent change has taken place in the medical arrangement of the parish, by which the work of the above individual and his assistant was divided between five medical men, one of whom had the workhouse. The parochial dispensary was abolished; two hundred pounds a-year were saved to the ratepayers; and this reform was loudly boasted of; nobody knowing, and very-few caring, how the poor were affected by the loss, or how the profession was benefitted by the robbery.

Did Dr. Kay and Mr. Chinnock, go on "reforming" after the most approved economical fashion? Or did the dues of their profession, and the wants of the sick poor, guide their hand in meteing to the future medical officers their full measure of labour, or in dealing out to them their scant measure of reward?

Let the fact be the answer. For a parish population of more than 32,000 persons, this Medical Guardian, and this Medical Commissioner, accepted as sufficient to defray the whole expense of the medical department, not $\$ 500$ as the old committee judged ten years ago; no, nor even the $\$ 300$ which the new, or radical, liberal committee adjudged-but $£ 215$ ! And, at 215 pounds a-year the sick poor of the parish, and the female infirmary of the Union, consisting of five parishps, with an aggregate population of $8 \tilde{0}, 500$ inbabitants, were left in the hands of Messrs. Marshall and Wilson, the two successful candidates.

At a meeting of Guardians, Mr. Chiunock expressed his conviction that the medical officers of all the Univas were too $x$ ell paid. And, upon being sharply rebuked by a lay 
Guardian, who deemed it very strange that a medical man should pass an opinion so well calculated to hinder justice from being done to his professional brethren, qualified his previous statement by saying he meant they were better paid than they ought to be upon the showing of the Poor-Law Commissioners. So much for one of the two Medical Guardians with which the Kensington Union has been blessed.

Before twelve months elapsed, a new election took place, and Chelsea returned Mr. Morrah, of Sloane-street, among the number of her Ginardiaus. The medical men of the Union all knew Mr. Chinnock to be an upstart, but the respectability of $\mathrm{Mr}$. Morrah was unquestioned; he had served the King 'in one of the military services, and was expected to serve the profession by his acquaintance with military usage. How he has done so we shall see.

A new distribution of medical districts is judged to be necessary. The Board of Guardians, after taking ten months to consider the matter, deemed the remuueration too small, and the labourers too few. And, intil the next change, there are to be three districts, and three medical officers. The gross amount of their saldries is to be increased from $£ 215$ to $£ 237$; and, as before, the Board very considerately calls Mr. MIorrah to its assistance, as the former Board had called Mr. Chinnouk; and by Mr. Morrah's science the Board is accordingly illuminated on its way. The two previous disticts are cut up to make a third; and the remuneration is to be as follows:-The north district, including the infirmary, is to afford $\mathbf{E 0}$, the south district $\mathbf{f t i 7}$, and the east, or new-fangled district, contrived by Mr. Norrah, $£ 80$ a-year. The future medical officer of the south district, whoever he may be, is indebted to a layman for even so large a proportion of these precious pickings. Mr. Morrah thought $£ 50$ a-year a very fair proportion of the $£ 237$ allotted to the entire purish. Althongh he might have known that the present medical officer of that district had found his duties so onerous, that they threw him upon a bed of sickness for many weeks; and although he ought to have known that the excess of out.door labour was on the south side of the parish, and would continue there under the new as well as under the old division.

But Mr. Chinnock and Mr. Morrah had their friends to serve; and however the former might think all the medical officers too well paid, there was one whom he thought not sufficiently well paid. That one was his own particulur private friend. Accordingly, in the second mouth of his reign as Guardian, this " most potent, grave, and reverend senor" called the attention of the Guardians to the comparative labours of Messis. Wilson and Marshall, in order to show how greatly more were those of the former than those of the latter; and, upon his showing, the too-credulous Board adopted his view of the case, and proposed a considerable increase upon the salary of the officer for the north district, and recom. mended such increase to the Commissioners, by whom it was refused.

So with Mr. Morrah, he, too, had his palty purpose to serve. And what do you sup. pose was that? the bestowal of a share of the medical piclings upon the medical men at the east or Sloame-street end of the parish / where, the candidate elect for the east district is said to reside; a gentleman, who was an unsuccessful candidate for the north dis. trict at each of the former elections.

Having dismissed these lesser stars of our patochial government, let us see how that great planetary body, Dr. Kay, has shed lustre upon his profession in our Union. $\mathrm{He}$, too, advised the laymen of the Board of Guardians, and his advice was adopted in their medical arrangements. This was his advice. Let your medicul officers be elected annually, you need not elect new mes, the election may be merely nominal. But in this way you can aluays get rid of a censur: able medical officer, without assigning hims reason, or giving him any right to un explaht. tion, by the mere exercise of your mdoubted power.

I can hardly, Sir, refrain from animad. verting upon these facts, for facts they are, facts capable of proof; but I must, in pity to your readers, deny myself; only, I do hope yon will pause before urging upon the Legislatule or the public, the proposal to have a Medical Commissioner and Medical Guardians. Every man in this parish, not a medical man, cries shame upon the medi. cal arrangements; while the only represen. tatives the profession has had, have been actively employed in completing those al. rangements.

If encouraged by you, I may perhaps furnish THE LANceT with a few articles on the subject of the parochial medical de. partment, in which it is my intention to develup a plan for the better treatment of the sick poor, and for the more adecuate, effectual, and honourable recompense of the parochial medical officer's, than any that has yet been offered.

In the meanwhile, let me conclude with only one question. Why should not all the medical officers of the respective Unions, be ex-officio members of the respective Boards of Guardians? The profession would then, indeed, be represented; and, better still, the sick poor would be represented also.

The good of our common profession must be my apology for this lengthened epistle, I am, Sir, your humble servant, Justitia et Misericordia.

Chelsea, J une 29, 1838. 
WE entirely agree with "Justice and Hercy" that the salaries of the medical offisers in the Kensington Union are entirely inadequate; but admitting, as the writer contends, that Messrs. Chinnock and Morrah have failed to urge upon the Guardians, measures for securing efficient attendance upon the sick poor, and that they have sacrificed the rights of the medical profession to the interests of the ratepayers, this is no argument against the appointment of a Medical Guardian. It is, in fact, a strong argument in favour of that step. Messrs. Chinnock and Morrah were elected by the ratepayers and served the ratepayers; the Medical Guardian to which we referred, would be elected by the medical men resident in the Kensington Union, and it would be the fault of "Justitia et Misericordia," and the friends of the profession, if their representative did not understand and uphold their rights and privileges. The Medical Commissioner would be appointed by the Crown and would not hold, as the Assistant Poor-Law Commissioners do, of the three Commissioners; he would be the friend of the medical profession, and contribute to place the whole system on an equitable footing. We recommend our correspondent to examine the medical evidence given before the Poor-Law Committee of the House of Commons.ED. L.

\section{NEW REGULATIONS OF THE COLLEGE.}

\section{To the Council of the College of Surgeons in London.}

( Gerteman:-You have recently issued regulations to be observed by students who may present themselves to be examined for the diploma of your College subsequently to the Session 1839-1810, in which you require the production of certificates of attendance for twenty-one months on surgical practice, six months on medical practice, and a more lengthened attendance on several courses of lectures.

Your are aware, Gentlemen, that it is not imperative for any student to obtain your diploma, and you are also well aware that you derive annually a large sum of money from gentlemen to whom you have given diplomas, and, of course, you must be the best judges whether the College could be supported without such receipts.

You have certainly improved your curriculum in requiring the candidate to be 21 years of age instead of 22 ; but you have sadly erred in obliging candidates to produce certificates of twenty-one months' surgical practice, and of having attended extended courses of lectures; depend upon it you never will malse either good surgeons or accomplished members by such al terations; no, you will, by such regulations, only retard the progress of those tudents who actually wish to cultivate their profession scientifically, but who, at the same time, wish to become members of the College; while, on the other hand, you will oblige those students who care nothing about the study of their profession, to obtain certificates which certify greater falsehoods. The road to good manner's is never too late to be taken, nevertheless it is never too soon; and permit me to inform you, Gentlemen, that faults are already more than half corrected, when those who have committed them become possessed of the moral courage to look into them. You had much better have left the surgical practice and attendance upon lectures to remain as formerly, or required none at all, and allowed all students both now and hereafter to present themselves for examination at the age of 21.

It is surprising that gentlemen like Sir A. Cooper, Sir A. Carlisle, Mr. Guthrie, Mr. Lawrence, \&c., should employ their minds in drawing up regulations which can only tantalise students who do intend, if possible, to pass the College.

I certainly contemplated presenting myself for examination, but I must give up all idea of doing so, provided these recent regulations are permitted to remain in force, and I know many students will do the same, for it was by no means uncommon, even previously to the publication of these recent regulations, to hear complaints against the enormous and unjustifiable fee demanded from candidates on becoming members.

In case the Council should not alter these tormenting regulations, I would ask the surgeons of the London hospitals if it is their intention to demand a larger fee from those students who will require certificates of twenty-one months' hospital practice. If they follow the example of the hospital physicians, they will not demand an increased fee. I am, Gentlemen, your obe. dient servant,

A Student of Guy's Hospital. London, July 18, 1838.

\section{CASE OF CATALEPSY.}

\section{To the Editor of ThE LANCET.}

Srr:-Well authenticated cases of cata. lepsy are so rare, that $I$ think it becomes every medical man to put any case of it on record which may come under his observation. The following example of this singular disease will, I trust, appear interesting 